\title{
Additional Leave as the Determinant of Retirement Timing-Retaining Older Workers in Norway
}

\author{
I Åsmund Hermansen' \\ Researcher, Fafo Institute for Labour and Social Research, Norway
}

\begin{abstract}
Faced with a rapidly aging labor force, increasing the labor supply of older workers has become an important goal for European countries. Offering additional leave to older workers with the option of withdrawing a contractual pension (contractual early retirement pension AFP) has become a widespread retention measure in Norwegian companies. Thus far, no studies documenting the effects of individual retention measures on early retirement behavior have been published. The aim of this article is to examine whether offering additional leave impacts the relative risk of withdrawal of a contractual pension. The analysis uses a difference-in-differences approach and examines whether offering additional leave to counteract early retirement impacts the retirement decisions of 61 - and 62 -year-olds within the next two years of their employment, controlling for a range of different individual and company characteristics. This is achieved by comparing changes and differences in the individual relative risk of retiring early on the contractual pension (AFP scheme) in the period 200 I-2010 among older workers in companies with and without the retention measure. The analysis shows an overall average increase in the relative risk of a 61 - or 62-year-old worker retiring on the contractual pension between 2001 and 2010; however, among older workers employed in companies offering additional leave there has been a decrease in the relative risk. The effect of additional leave is evident both before and after controlling for the selected individual and company characteristics. Thus, the analysis shows that offering additional leave as a retention measure reduces the individual relative risk of withdrawing a contractual pension (AFP) in the next two years of employment among older workers between the age of 61 and 62 years.
\end{abstract}

\section{KEYWORDS}

Additional leave / early retirement / older workers / retention measures

\section{Introduction and research question}

M

any European countries are facing a demographic change that makes increasing the labor supply of older workers an important goal. The effects of an aging population on the sustainability of the welfare state in general and on social security systems in particular have been extensively studied and discussed in the research literature (Disney, 1996, Esping-Andersen, 2000, Meier and Werding, 2010). With the aim of reducing early retirement and increasing the length of employees' working lives, several European governments have implemented policies supporting age management strategies at the company level (Taylor, 2006). In the EU, the so-called Lisbon Strategy led to the "Barcelona target" in 2002, demanding that every EU member state sought

1 Åsmund Hermansen, Fafo Institute for Labour and Social Research, Box 2947 Tøyen, 0608 Oslo, Norway. E-mail: ahe@fafo.no 
an increase in average retirement age of about five years by 2010. Reaching macroeconomic targets of this kind is unlikely to be met without the active support of employers (Conen et al., 2011, Hofäcker, 2010). Both in the EU and Norway the heightened focus on age management strategies has fostered a growing interest in retention measures for counteracting early retirement (Kooij et al., 2013). Offering additional leave to workers from the age of 62 years who have the option to withdraw a contractual pension (the contractual early retirement scheme AFP) has become a widespread retention measure in Norwegian companies. All Norwegian employees are by law entitled to one additional week of leave from the age of 60 years. Thus, additional leave in this article refers to extra days off beyond the statutory "senior week" 1 offered on a voluntary basis by Norwegian companies. In 2010 more than $20 \%$ of companies with ten or more employees offered their older workers additional leave (Midtsundstad and Bogen, 2011).

The research literature on retirement behavior demonstrates the great complexity of the beliefs, desires, and opportunities determining older workers' transition between work and retirement. The common thread in this research is the recognition that older workers have different work histories and as such have different expectations of work and retirement (Flynn, 2010, Hedström, 2005). The effect of additional leave presupposes that more leisure time is a motivating factor to continue working for employees who would otherwise retire on the contractual pension. The question of whether or not offering additional leave is effective in preventing older workers making an early exit has thus far remained unanswered (Midtsundstad et al., 2012a). The aim of this article is to examine whether offering additional leave has an effect on the relative risk of withdrawal of a contractual pension.

\section{Theoretical framework}

Understanding the transition from work to retirement and the role played by additional leave as a retention measure rests on our ability to recognize the variety of factors influencing early retirement practices. Theoretical traditions within the research literature on early retirement behavior present the different factors influencing labor supply in the final phase of working life. Different perceptions of the factors used to explain early retirement stem from differences in the notion of whether the exit is voluntary or involuntary and whether it is mainly affected by labor supply or labor demand (Engelhardt, 2012, Hedström, 2005, Jensen and Øverbye, 2013, Midtsundstad et al., 2012a). These competing theoretical traditions provide the basis for explaining how additional leave may function as a retention measure by emphasizing features which coincide with the theoretical tradition at hand.

Working on the assumptions that individuals desire to maximize their lifetime earnings and that the exit of older workers from the labor market is voluntary, the economic theory of retirement has been the most influential theoretical approach in academic debates on early retirement (Engelhardt, 2012). This theoretical approach explains early retirement as the outcome of an individual and rational decision-making process, where each individual weighs the pros and cons related to work and leisure. Desiring leisure over work, utility-maximizing workers select the time they believe is optimal to retire, taking into consideration financial opportunities and constraints (Engelhardt, 2012). The opportunities for different action alternatives are determined by the accessibility 
and performance of the various pension schemes available, which are decisive in making the choice between work and leisure. Payment levels and corresponding tax rates, age restrictions, and selection criteria act as factors "pulling" employees out of working life early. Hence the labor market exit of older workers can be traced back to the financial incentives to retire offered by early retirement pension schemes and other welfare-state programs (Engelhardt, 2012, Gambetta, 1987, Gruber and Wise, 2007, 2010, Hernæs et al., 2002). For an individual desiring to maximize lifetime earnings as well as more leisure time, being offered additional leave represents a new opportunity to gain more leisure while continuing paid employment. Thus, from this theoretical viewpoint, additional leave adds to the pros for continuing working, motivating the choice of later exit over early retirement against other factors "pulling” older workers out of work.

Within the literature on early retirement, "pull factors" have often been related to purely economic incentives and a preference for leisure over work. However, within the field of sociology these factors have also been given a more social and cultural understanding. From a sociological point of view, early retirement schemes also reproduce the culturally constructed notion of when older workers should leave the labor market (Jensen and Øverbye, 2013). Thus, early retirement schemes are assumed to represent institutional expressions of values, norms, and conventions pertaining to when older workers should leave the labor market. Acting upon the signals embedded in early retirement schemes, individuals are "pulled" out of working life early. Hence, these early retirement schemes have underpinned an "early exit" regime through influencing when older workers believe they are supposed to retire (Jensen and Øverbye, 2013). From this sociological perspective, offering additional leave may help counteract these culturally constructed notions of when older workers should leave the labor market. Besides, offering older workers more leisure time, such a measure also signals the employer's wish for older workers to continue working in the company. Hence, offering additional leave may motivate older workers to continue working for a few more years by counteracting an "early exit" regime and the culturally constructed beliefs about when older workers should leave the labor market. Thus, the signal effect may also be of importance when older workers are weighing the pros and cons of continuing working against those of leaving the labor market altogether.

The economic theory of retirement has been criticized for modeling the transition between employment and retirement as a voluntary choice (Engelhardt, 2012). The approach neglects the labor demand side, focusing exclusively on the individual decision and hence taking a singular labor supply view. In response to this one-sided focus on free individual choice and "pull factors," a growing research literature is focusing on involuntary retirement as a result of "push factors." This includes "labor market and company-level push factors" such as structural adjustments, rationalization, increased eligibility requirements, and other factors that "push" elderly, less productive, or less skilled labor out of the labor market (Dorn and Sousa-Poza, 2010, Gambetta, 1987, Halvorsen, 1977, Midtsundstad, 2007). Referred to as "individual push factors," health problems, as well as physical and mental strains related to the job, have proven to increase the likelihood of older workers opting for early retirement (Buchholz et al., 2006, Börsch-Supan et al., 2009, Calvo et al., 2013, Engelhardt, 2012, Gørtz, 2012, Midtsundstad, 2006). Offering additional leave in the final phase of working life may help older workers to reconcile work and the need for more leisure, reducing the burdens which may otherwise "push" them out of working life early. 
As a retention measure, additional leave may counteract "push" as well as "pull factors," extending the working life of older workers with the option of withdrawing a contractual pension. However, analyses explaining the factors of early retirement practices which emphasize only "pull" or "push factors" have proven to be inadequate. Both sets of factors are relevant as there may be a variety of factors influencing early retirement behavior. Thus, analyses of early retirement behavior must include a model which sufficiently recognizes the variety of factors influencing early retirement practices.

The aim of this study is to investigate whether additional leave works as a retention measure on the whole, counteracting either "pull" or "push factors," or a combination of both. The role played by additional leave as a retention measure and which factors are decisive in the decision to prolong working life will vary between individuals according to differences in beliefs, desires, and opportunities. Retirement practices may also vary according to experiences outside the workplace, such as family situation and spouse retirement behavior (Hallberg, 2007, Hank, 2004, Hauge and Årethun, 2008, Oude Hengel et al., 2012). Thus, an analysis of early retirement behavior must also include variables accounting for such characteristics. In order to be able to investigate the effect of additional leave on the withdrawal of a contractual pension, the analysis will include a range of independent variables accounting for "pull and push factors" which previous research has shown to affect early retirement behavior.

\section{Previous research}

Studies show that offering additional leave is a widespread retention measure among employers in many European countries (Conen et al., 2011, 2012, Van Dalen et al., 2009, 2010). In a study of Dutch employers, Van Dalen et al. (2010) found additional leave for older workers to be the most common retention measure; the second and third most common measures were ergonomic measures and partial retirement, respectively. A study by Conen et al. (2011) shows that the number of Dutch employers offering additional leave decreased between 2000 and 2009. In 2000, 53\% of employers offered additional leave as a retention measure and in 2009 the figure had dropped to $44 \%$. Nevertheless, offering additional leave was still the most common retention measure used by Dutch employers.

In a study of Norwegian employers conducted in 2005, Midtsundstad (2007) found that only $2 \%$ used additional leave as a retention measure. Providing alternative work tasks $(11 \%)$ and different facilitation/ergonomic measures $(21 \%)$ were the most common measures for retaining older workers. Nevertheless, a vast majority of employers offering measures providing greater flexibility, such as additional leave, meant that these measures helped delay retirement. Accordingly, in a study of older workers in the government sector, Reichborn-Kjennerud et al. (2011) found that older workers emphasize additional leave as an important incentive for continuing working beyond the age of 62 years, which is the age at which employees are entitled to withdraw the contractual pension. In another Norwegian study of older workers in the municipal sector, Midtsundstad and Nielsen (2013) also found that a large number of older workers emphasized additional leave as an incentive for continuing working. Thus, studies among both employers and employees show that both groups deem additional leave an effective retention measure. 
The study carried out by Reichborn-Kjennerud et al. (2011) was based on a heavily biased sample given the fact that the survey population consisted exclusively of older workers aged 60 years and above, who were all still working. Workers aged 60 years and above can be assumed to be more healthy and motivated to work than the population of older workers as a whole, since a large proportion of employees retire on the disability pension before they turn 60 years (Midtsundstad et al., 2012a). Taking this into account, Reichborn-Kjennerud et al. (2011) acknowledged that their findings may not be valid in other sectors with greater physical and mental strains. They stress the fact that the older workers emphasizing additional leave as a decisive factor in the decision to continue working were mostly highly educated and reported to be of good health.

Surveys show that many early retirees justify opting for early retirement on the basis of a need for more leisure time, thus additional leave may provide older workers with the necessary flexibility and leisure to continue working a few years more (Midtsundstad, 2007, 2009, Midtsundstad and Nielsen, 2013). Using the first three waves of the Health and Retirement Study (1992 to 1996), Charles and DeCicca (2007) discovered that older American workers who were not free to lower their usual working hours, workers who are hours-constrained or overemployed, are much more likely to retire than workers who are free to adjust their hours of work. These findings hold true for both sexes, but the lack of flexibility had the greatest effect on men. Studying the presence of hours' constraints in the UK labor market, Gielen (2009) supports these findings, showing that some overemployed woman in the UK, especially those working full-time, left the labor market early due to lack of gradual retirement opportunities with their current employer.

A review of previous research on measures for retaining older workers in Midtsundstad et al. (2012a, 2012b) shows that few policies and facilitation programs for older workers have been evaluated, and that the correlation between the supply of labor and facilitation for older workers, such as additional leave, is ambiguous. The few Norwegian studies that have evaluated the impact of retention measures for older workers on early retirement behavior showed that offering such measures in 2005 did not always help to delay retirement (Midtsundstad et al., 2012a, 2012b). However, the aim of these studies was not to evaluate the impact of individual retaining measure, such as additional leave, but to evaluate the overall effect of being offered retention measures. Furthermore, very few companies had initiated such measures by 2005 compared with the 2010 situation (Midtsundstad et al., 2012a, 2012b). Hence, further analysis of the effects of the measures used by companies to retain older workers is needed.

\section{The labor market in Norway}

Norway has one of the highest employment rates among 55- to 64-year-olds in Europe and an employment rate above the OECD average (OECD, 2013). This can be explained by four factors. Firstly, compared to other European countries, Norway had until 2011 a relatively high statutory retirement age (67 years for both men and women). Secondly, the possibility of retiring at the age of 62 years was first given to Norwegian employees in 1998 through the contractual pension (AFP scheme), covering about $80 \%$ of all older workers (Midtsundstad, 2004, Nergaard, 2009). ${ }^{2}$ Thirdly, from 1997 the contractual pension also allowed individuals to combine part-time work with a partial pension. 
However, employees wishing to combine part-time work with a part-time contractual pension must obtain the agreement of their employer. Fourthly, redundancy regulations in Norway follow the "last in, first out" principle, making dismissal protection in Norway especially strong for older workers with seniority (Midtsundstad, 2011).

The increased attention to the aging part of the workforce in Norway is manifested by the Inclusive Working Life Agreement (IWLA), which set out to increase the average retirement age between 2001 and 2010 and from 2010 to increase the total years in employment. With the signing of the IWLA in 2001, the government called for employers to take greater social responsibility for keeping people in employment until they reach pensionable age. The majority of Norwegian employers do indeed admit that they have-and also insist on taking-social responsibility for keeping people in employment, a responsibility largely limited to their own employees (Midtsundstad, 2008). In addition to signing the IWLA, in 2010 nine out of ten IWLA companies had implemented active aging or life-stage policies aimed at retaining their older workers (Midtsundstad and Bogen, 2011). The average retirement age in Norway has increased since 2001 and the introduction of the IWLA (Haga, 2010). Nevertheless, whether the reduction in the rate of early retirement is a direct effect of the measures aimed at retaining older workers remains unclear (Midtsundstad et al., 2012a).

\section{The contractual pension scheme and additional leave as a measure for retaining older workers}

The contractual pension or contractual early retirement scheme (AFP scheme) offers older workers the possibility of opting for early retirement between the ages of 62 and 66 years. From January 1, 2011, the contractual pension was changed to a flexible lifelong annuity for private sector workers, making the scheme distinctly different from the public sector where it is still designed as an early retirement scheme. Nevertheless, this regulatory change was implemented after the timespan investigated in this article. Early retirement was available to all public sector workers and about $40 \%$ of private sector workers (the scheme was optional for private sector companies) (Midtsundstad, 2004, Nergaard, 2009).

The financing of the contractual pension is organized as a common redistribution system and employers pay a pension premium for their employees. However, from 2004 employers in municipality sector could choose to opt out of the common redistribution system and carry $50 \%$ or $100 \%$ of the total cost when employees retire on the contractual pension. In the private sector the scheme was also arranged as a common redistribution system (until 2011). The private sector scheme was partially paid by the state (one-third) and partially paid by pension premiums from the employers (two-thirds). Besides the pension premium, the most common arrangement was that private sector employers carried $25 \%$ of the total cost when their own employees retired on the contractual pension. In the state sector, the employers only pay a pension premium into the common redistribution system and do not bear any additional cost when employees retire. Thus, those municipalities which have opted out of the common redistribution system have a financial incentive to retain their older workers. In addition, private sector employees with a contractual pension did also have a financial incentive to retain workers from retiring early (until 2011).

The most common entitlement age for retention measures used by Norwegian companies is 62 years. This is the age at which $74 \%$ of the 61 - and 62 -year-olds working 
in companies offering additional leave as a retention measure became eligible for the additional leave in 2010. The most common arrangement was five days or more additional leave, the amount available to $87 \%$ of the 61 - and 62 -year-olds working in companies using the retention measure. Furthermore, the number of companies offering additional leave as a retention measure was quite low prior to 2005 , with only $4 \%$ of companies offering additional leave. Additional leave gained greater popularity from 2005; by 2006 almost $10 \%$ of Norwegian companies with ten or more employees offered additional leave as a retention measure, with that number increasing to $21.5 \%$ by 2010 (Midtsundstad and Bogen, 2011).

\section{Data}

The data used in the analysis cover the period 2000 to 2010 and comprise all employees between 61 and 62 years of age $(\mathrm{N}=15,231)$ who were employed in any of the 361 companies that participated in a 2010 survey. The sample was representative for all Norwegian companies with ten or more employees in 2010 and one or more employees between 61 and 62 years of age. The survey was conducted by the Fafo Institute for Labor and Social Research and Respons Analyse in the period August to September 2010 and yielded a response rate of $60 \%$. The companies were contacted by telephone and the interviewers asked initially for the HR manager (in the case of smaller companies, the general manager). The sample universe was The Register of Business Companies $^{3}$ in August 2010. The survey provides information on company characteristics and whether additional leave is used as a retention measure on early retirement and, if so, in which year the measure was introduced (Midtsundstad and Bogen, 2011). All information on individual employees has been provided by Statistics Norway (SSB) and is drawn from administrative registers. In the private sector only employees working in a company which offers the contractual pension (AFP) are included in the analysis. In the public sector all employees have access to the contractual pension and are accordingly included in the analysis. Of the 361 companies that participated in the 2010 survey, 100 are in the public sector and 261 in the private sector.

\section{Method}

The analysis uses a difference-in-differences approach which enables the measurement of changes in the individual relative risk of retiring on the contractual pension before and after the introduction of additional leave. These differences in average change are also referred to as a Difference-in-Differences estimator (Angrist and Pischke, 2008, Wooldridge, 2009). This is a standard method for measuring the effects of interventions and regulatory changes. The method consists of comparing two groups, where one group experiences a policy change-in this analysis additional leave-during the period under consideration (Angrist and Pischke, 2008, Wooldridge, 2005, 2009). The survey provides information on which companies have introduced additional leave, in which year the measure was introduced, and details relating to the additional leave offered.

The analysis investigates whether working in a company offering additional leave affects the relative risk of workers aged 61 and 62 years, in the period 2000 to 2008, 
retiring on the contractual pension in the next two years of their employment. A company is identified as offering additional leave as a retention measure on the basis of the HR manager/executive director of the company in August-September of 2010 having reported to have made this measure available to older workers with the purpose of encouraging them to continue working (Midtsundstad and Bogen, 2011). Among the companies having introduced additional leave as a retention measure, only those having introduced the measure from 2005 and with an entitlement age set at 62 years are included in the analysis. In addition, only those companies offering five days or more additional leave are included. Thus, the analysis investigates the relative risk of 61 - and 62-year-olds retiring in the next two years of their employment during a period when none of the companies in the data had initiated this retention measure, compared with the relative risk of the workers retiring during a period when a known selection of the companies had introduced the measure. The first period is referred to as the pretreatment period, 2001/2002 to 2004/2005, the second period, 2005/2006 to 2009/2010, is referred to as the posttreatment period. The argument for choosing to exclude companies that introduced additional leave as a retention measure before 2005 is to provide a clearer delimitation between the pre- and posttreatment period. Furthermore, delimiting the treatment group to those who work in companies where the entitlement age is set at 62 years and who are offered five days or more additional leave enables the analysis to investigate the effect of measures offered on similar grounds. The control group includes workers aged 61 and 62 years employed in companies which did not introduce additional leave as a retaining measure during the period under consideration.

All analyses were performed using Stata, version 12. Given that the dependent variable is binary categorical, logistic regression has been employed in the analysis and odds ratios are reported. The two models, presented in Table 2, have also been estimated as linear probability models, yielding substantially similar results (not shown). Model 1 investigates the total effect of offering additional leave. This is done by including the retention measure as a dummy variable, a dummy for separating the pretreatment period (0) and posttreatment period (1), measuring the overall change and the interaction between the change and the retention measure (Difference-in-Differences estimator). Thus, model 1 provides an estimate of the gross effect of offering additional leave.

Offering additional leave is a choice made by each individual company and hence the group of Norwegian companies offering this retention measure is self-selected. However, the distribution of older workers in the intervention group and the control group can be assumed to be random, given the fact that very few change jobs after the age of 60 years, enabling them to actively seek out companies with such retention measures for older workers (Lien, 2013, Midtsundstad et al., 2012a, OECD, 2013). However, in order to be able to measure the true effect of providing additional leave, the two groups are assumed to be comparable over time. Such an assumption is not very likely, thus model 2 includes controls for various individual and company characteristics.

\section{Model}

To account for possible differences in the early retirement behavior between women and men, "woman" is included in the analysis ("male" ref.). The analysis also included "living in a one-person household" (not living in a one-person household ref.), controlling 
for household status, and a possible desire to spend more time with family, making older workers "jump" into retirement.

One of the limitations of the data applied in the analysis is the lack of variables controlling for differences in health, working environment, and working conditions between the intervention and control group. However, controlling for "sick absence" and "level of education" does presumably capture important differences in health, working environment, and working conditions between the intervention and the control group. Thus, the analysis includes "sick absence" ("sickness absence" certified by a physician and lasting for more than 16 days, "no sick absences" ref.) and level of education divided into "elementary school" (ref.), "high school," "undergraduate from university/ college," and "postgraduate from university/college." As illustrated in Table 1, the intervention group has a slightly lower proportion of employees with "elementary school" as their highest level of education and a higher proportion with "high school," hence level of education is also included to control for this difference.

To account for the effect of financial incentives presumably "pulling" older workers into early retirement, "income percentile" (net income after tax divided into percentiles), "spouse income percentile" (spouse income after tax divided into percentiles), and "household debts percentile" (household debts divided into percentiles) are included in the analysis.

Research on the relationship between marital status and economic activity-or "coupled retirement"- shows that many couples "coordinate" their retirement. The tendency for couples to make a joint exit from working life is known as "the joint retirement hypothesis" (Charles and DeCicca, 2007, Hank, 2004, Lancee and Radl, 2012). To control for the possibility that couples "coordinate" their retirement, the analysis includes "spouse retired on the contractual pension" and "spouse retired on disability pension." Working hours have also shown to affect when older workers leave the labor market, especially those working part-time has a higher relative risk of being disabled (Midtsundstad et al., 2012a, 2012b). To account for the effect of working hours, contractual working hours, that is, "full-time" (ref.), "long part-time" (from 50\% to $80 \%$ full-time equivalent), and "short part-time" (less than 50\% full-time equivalent), are included in the analysis.

Research shows that "workers" and "routine nonmanual employees" often retire due to health problems, heavy professional burdens, and long careers, whereas "professionals, administrators, or officials" are more inclined to retire due to loss of interest and motivation (Midtsundstad, 2002, 2005). To account for differences in early retirement behavior among employees in different occupations and the fact that the intervention group has a higher proportion of "workers," occupation is included in the analysis. In addition to "sick absence" and level of education, controlling for occupation may account for possible differences in health, working environment, and working conditions between the intervention and control group. The classification of the different occupations is based on the Erikson-Goldthorpe social class schema using the International Standard Classification of Occupations (ISCO88) which distinguishes between "workers," "routine nonmanual employees," and "professionals, administrators, and officials" (ref.) (Leiulfsrud et al., 2005).

Studies show that companies in which work is allocated to teams, making employees mutually dependent on each other to perform their tasks, are less inclined to offer older workers flexible working time arrangements (Hutchens, 2010, Latulippe and Turner, 
Table I Distribution by independent variables

\begin{tabular}{|c|c|c|c|c|}
\hline & \multicolumn{2}{|c|}{$2001 / 2002-2004 / 2005$} & \multicolumn{2}{|c|}{$2005 / 2006-2009 / 2010$} \\
\hline & $\begin{array}{l}\text { Intervention } \\
\text { group }\end{array}$ & $\begin{array}{l}\text { Control } \\
\text { group }\end{array}$ & $\begin{array}{l}\text { Intervention } \\
\text { group }\end{array}$ & $\begin{array}{l}\text { Control } \\
\text { group }\end{array}$ \\
\hline Woman & 62.7 & 64.6 & 61.2 & 61.6 \\
\hline Living in a one-person household & 18.4 & 20.3 & 17 & 22.1 \\
\hline Sick absence & 19 & 17.1 & 12 & 13.3 \\
\hline Elementary school & 22.4 & 25.3 & 15.2 & 18.6 \\
\hline High school & 47.5 & 41.2 & 49.2 & 40.4 \\
\hline Undergraduate from university/college & 22.4 & 26.8 & 26.7 & 31.2 \\
\hline Postgraduate from university/college & 7.7 & 6.7 & 8.9 & 9.8 \\
\hline Income percentile, mean (s.d.) & $48.8(29.4)$ & $49(29)$ & $47.9(29.4)$ & $51.4(29)$ \\
\hline Spouse income percentile, mean (s.d.) & $43.3(29.7)$ & $42.7(31.6)$ & $45.7(30.1)$ & $44.8(33)$ \\
\hline Household debts percentile, mean (s.d.) & $36.6(29.8)$ & $39.4(29.5)$ & $40.9(29)$ & $44(29.2)$ \\
\hline Spouse retired on AFP retirement scheme & 7.5 & 6.8 & 6.6 & 5.9 \\
\hline Spouse retired on disability pension & 16.9 & 16.2 & 16.4 & 13.5 \\
\hline Full-time 30 hours or more & 66.8 & 67.2 & 71 & 73 \\
\hline Part-time 20-29 hours & 15.7 & 15.1 & 13.3 & 12.4 \\
\hline Part-time $<20$ hours & 17.5 & 17.7 & 15.7 & 14.7 \\
\hline Worker & 58.8 & 48 & 58 & 35.2 \\
\hline Routine nonmanual employee & 13.4 & 36.7 & 20.6 & 40 \\
\hline Professional, administrator, or official & 27.8 & 15.3 & 21.4 & 24.8 \\
\hline I00 or more employees & 93 & 77.4 & 92.2 & 84.7 \\
\hline Human resources manager & 98.6 & 92 & 96.8 & 92.7 \\
\hline Public administration & 26.3 & 5.6 & 30.8 & 3.2 \\
\hline Other industries & 7.9 & 12.5 & 9.6 & 17.3 \\
\hline Teaching & 34.9 & 32.6 & 16.2 & 34.5 \\
\hline Health and social services & 22.8 & 24.4 & 28.7 & 21.6 \\
\hline Manufacturing & 2.8 & 11.3 & 5 & 9.6 \\
\hline Construction & 2.9 & 3.4 & 1.8 & 1.6 \\
\hline Hotels and restaurants & 0.1 & 3.2 & 0.5 & 4.2 \\
\hline Wholesale and retail trade & 2.2 & 7.3 & 7.3 & 8 \\
\hline Not IWLA company & 33.3 & 38.6 & 35.1 & 57.8 \\
\hline IWLA company 200I & 7.7 & 8.4 & 12.2 & 6.4 \\
\hline IWLA company 2002-20I0 & 59 & 53 & 52.7 & 35.8 \\
\hline $\begin{array}{l}\text { Number of other retention measures, } \\
\text { mean (s.d.) }\end{array}$ & $1.4(0.8)$ & $0.5(0.8)$ & $1.5(0.8)$ & $0.3(0.5)$ \\
\hline N & 4,077 & 2,521 & 6,259 & 2,374 \\
\hline
\end{tabular}


2000, Midtsundstad and Bogen, 2011). However, the possibility of offering retention measures facilitating more flexibility, such as additional leave, can be expected to increase with the size of the company even if work is allocated to teams. A larger workforce allows more leeway for adjusting production to a reduction in working hours among the older workers. As illustrated in Table 1, the intervention group has a higher proportion of employees working in companies with " 100 or more employees." To control for number of employees and the difference between the intervention and control group, "100 or more employees" is included in the analysis ("less than 100 employees" ref.).

The "human resources manager" holds an important role in facilitating working conditions which safeguard the needs of employees and advocating adaptions to account for these needs. Thus, a "human resources manager" may play an important role in adjusting working conditions in accordance with the needs of older workers, providing them with the possibility of extending their working life. As illustrated in Table 1, the intervention group has a slightly higher proportion of employees working in companies with a "human resources manager." "Human resources manager" is included in the analysis as a dummy variable ("No human resources manager" ref.).

The type of industry has proven to influence whether older workers make an early exit from working life. Traditional industries such as "manufacturing" experience global technological changes and the growing international division of work, which in turn has led to higher rates of older workers opting for early retirement. Working in industries such as "manufacturing" and "construction" will presumably involve more heavy manual labor than working in "public administration," thus controlling for industry may account for some of the possible differences in working environment and working conditions between the intervention and control group (Buchholz et al., 2006, Midtsundstad et al., 2012a, 2012b). As illustrated in Table 1, the intervention group has a higher proportion of workers employed in "public administration" and a lower proportion employed in "manufacturing." To control for type of industry and the differences between the intervention and control group, the analysis includes "public administration" (ref.), "other industries," "teaching," "health and social services," "manufacturing," "construction," "hotels and restaurants," and "wholesale and retail trade."

The intervention group has a higher proportion of employees working in companies which signed the IWLA between 2002 and 2010. As illustrated in Table 1, having other retention measures available to them is also more common for employees in the intervention group. To control for these differences between the intervention and control group, "IWLA company 2001," "IWLA company 2002-2010" ("not IWLA company" ref.), and "number of other retention measures" are included in the analysis.

\section{Results}

Early retirement behavior in the period and companies under consideration is illustrated in Figure 1. Employing a difference-in-differences approach rests on an assumption that the underlying trends in the outcome variable would be the same in the absence of treatment (Angrist and Pischke, 2008). As illustrated, there are only minor variations in retirement rates between the treatment and the control group in the pretreatment period from $2001 / 2002$ to $2004 / 2005$ and the overall trend is a small increase in both groups. Thus, Figure 1 provides visual evidence of an equal underlying trend in the pretreatment period. 
Figure I: Percentage of 61 - and 62-year-olds withdrawing a contractual pension in the next two years of employment and working in companies offering additional leave as a retention measure compared to the percentage working in companies without such an arrangement for older workers.

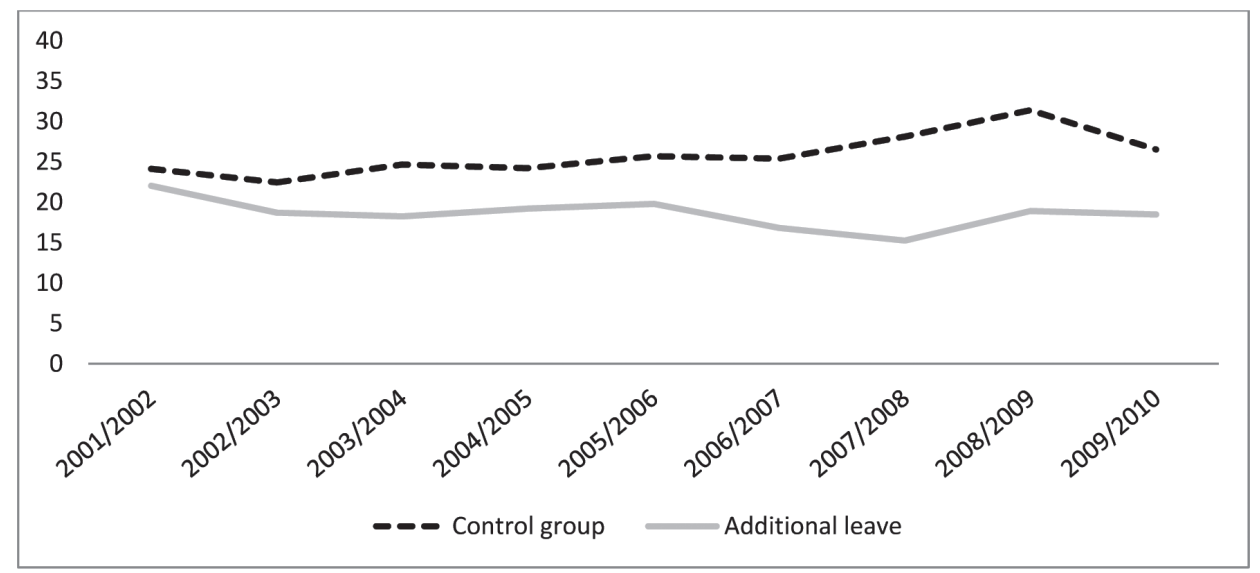

In the posttreatment period from 2005/2006 to 2009/2010, the treatment group experiences a fall in early retirement rates whereas in the control group early retirement rates continue to increase. Thus, the difference between the early retirement rates of the treatment and control groups is more significant in the posttreatment period than in the pretreatment period.

As a robustness check, in addition to investigating the trends in the pretreatment period in Figure 1, the analysis also includes a "placebo difference-in-differences" test (not shown) pretending that additional leave was employed among the intervention companies in 2003 and not from 2005 onward; 2001/2002 to 2002/2003 was used as the pretreatment period and $2003 / 2004$ to $2004 / 2005$ as the posttreatment period. The "placebo difference-in-differences" test did not yield significant results, strengthening the assumption that the trends were quite similar in the posttreatment period and that there were no unobserved trends affecting one of the groups, but not the other.

As illustrated in Table 1, the proportion of "workers" and the proportion working in a "IWLA company 2002-2010" in the control group changes from the pretreatment to the posttreatment period. Additionally, in the treatment group the proportion working in "teaching" changes from the pretreatment to the posttreatment period. To control for these changes the analysis included interactions between the respective confounders and the dummy for change from the pretreatment to the posttreatment period (not shown). To control for clustered data on company level, the analysis also included a regression using clustered standard errors (not shown). The regression results using clustered standard errors and including these interactions did not differ from the results presented in Table 2 using normal standard error and not including the respective interactions.

The analysis shows an overall average increase in the relative risk of a 61- or 62-yearold worker retiring on the contractual pension between 2001 and 2010 ("change from pretreatment period to posttreatment period"); however, among older workers employed in companies offering additional leave there has been a decrease in the relative risk ("Retention measure" change (Difference-in-Differences estimator)"). The effect of 
Table II Individual relative risk of withdrawing a contractual pension among 61- to 62-year-olds in the next two years of employment, having been exposed to additional leave as a retention measure, before and after controlling for a range of individual and company characteristics.

\begin{tabular}{|c|c|c|}
\hline & $\begin{array}{l}\text { Model I } \\
\text { OR }\end{array}$ & $\begin{array}{l}\text { Model } 2 \\
\text { OR }\end{array}$ \\
\hline Woman & & 0.904 \\
\hline Living in a one-person household & & 0.865 \\
\hline Sickness absence & & $1.439 * * * *$ \\
\hline Elementary school (ref.) & & 1.000 \\
\hline High school & & 0.978 \\
\hline Undergraduate from university/college & & 0.888 \\
\hline Postgraduate from university/college & & 0.665 **** \\
\hline Income percentile & & $0.995 * * * *$ \\
\hline Spouse income percentile & & $1.006 * * *$ \\
\hline Household debts percentile & & $0.994 * * * *$ \\
\hline Spouse retired on contractual pension & & $1.394 * * * *$ \\
\hline Spouse retired on disability pension & & 1.070 \\
\hline Part-time $<20$ hours (ref.) & & 1.000 \\
\hline Part-time $20-29$ hours & & $2.487 * * * *$ \\
\hline Full-time 30 hours or more & & $2.644 * * *$ \\
\hline Professional, administrator, or official (ref.) & & 1.000 \\
\hline Routine nonmanual employee & & 1.104 \\
\hline Worker & & 0.952 \\
\hline Less than 100 employees (ref.) & & 1.000 \\
\hline I00 or more employees & & $1.329 * * * *$ \\
\hline No human resources manager (ref.) & & 1.000 \\
\hline Human resources manager & & 1.083 \\
\hline Public administration (ref.) & & 1.000 \\
\hline Other industries & & $2.327 * * * *$ \\
\hline Teaching & & $1.626 * * * *$ \\
\hline Health and social services & & I.148*** \\
\hline Construction & & $2.152 * * * *$ \\
\hline Manufacturing & & $3.392 * * * *$ \\
\hline Hotels and restaurants & & $2.185 * * * *$ \\
\hline Wholesale and retail trade & & $2.483 * * * *$ \\
\hline Not IWLA company (ref.) & & 1.000 \\
\hline IWLA 200I & & 0.996 \\
\hline IWLA 2002-2010 & & 1.075 \\
\hline Number of other retention measures & & 1.063 \\
\hline Retention measure-additional leave & $0.735 * * * *$ & $0.799 * * * *$ \\
\hline Change from pretreatment period to posttreatment period & $1.195 * * * *$ & 1.214 ***** \\
\hline Retention measure*change (Difference-in-Differences estimator) & 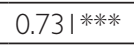 & 0.721 米*** \\
\hline Pseudo R2 & 0.008 & 0.063 \\
\hline $\mathrm{N}$ & $|5,23|$ & $|5,23|$ \\
\hline
\end{tabular}


additional leave is evident both before and after controlling for the selected individual and company characteristics. There is almost no change in the Difference-in-Differences estimator when controlling for the different confounders in model 2. Thus, the results provide evidence for additional leave having an impact on the individual relative risk of withdrawing a contractual pension. The reducing effect of additional leave on the individual relative risk of withdrawing a contractual pension is estimated to be slightly above $5 \% .{ }^{4}$ As shown in Figure 1, the difference in aggregated retirement rates between the treatment and control group diminishes toward the end of the timespan investigated. However, the analysis investigates the changes in the individual relative risk of withdrawing a contractual pension and not the changes in the companies' numbers of early retirees as illustrated in Figure 1.

The relative risk of a 61- or 62-year-old withdrawing a contractual pension in the next two years of their employment is lower for those with a "postgraduate from university/college" and also decreases with "income percentile" and "household debts percentile." The relative risk of retiring early increases with having a "sick absence," "spouse income percentile," and a "spouse retired on contractual pension." Compared with "public administration," the relative risk of retiring on the contractual pension is higher for older workers in all other industries. Working "more than 20 hours per week" or "full-time" also increases the relative risk of retiring on the contractual pension, compared to those working "less than 20 hours per week." Furthermore, working in a company with "100 or more employees" increases the relative risk of retiring early.

\section{Discussion}

The few Norwegian studies that have evaluated the impact of retention measures for older workers on early retirement behavior showed that offering such measures in 2005 did not always help to delay retirement (Midtsundstad et al., 2012a, 2012b). However, the aim of these studies was not to evaluate the impact of individual retaining measure, such as additional leave, but to evaluate the overall effect of being offered retention measures. Furthermore, very few companies had initiated such measures by 2005 compared with the 2010 situation (Midtsundstad et al., 2012a, 2012b). Adding to these studies, the aim of this article was to investigate the possible effect of additional leave on early retirement, based on the 2010 situation. The results in this article show that working in a company offering additional leave for older workers reduces the relative risk of 61- and 62-year-olds withdrawing a contractual pension in the next two years of their employment. The effect ${ }^{5}$ of additional leave is evident both before and after controlling for a range of known individual risk factors such as gender, level of education, level of income, one-person household, contractual working hours, and occupation, as well as after controlling for company characteristics such as the number of employees, the presence of a human resources manager, industry, and the time of joining the IWLA. Hence, the effect of additional leave cannot be ascribed to differences in these respects between the intervention group and the control group. The results therefore support a notion of more leisure time being a motivating factor for workers aged 61 and 62 years who would otherwise retire on the contractual pension to instead continue working.

Offering additional leave in the final phase of working life may help older workers to reconcile work and leisure, thus reducing the burdens which may push older workers 
out of working life early. Health problems, as well as physical and mental strains related to the job are important reasons for retiring early (Buchholz et al., 2006, Börsch-Supan et al., 2009, Calvo et al., 2013, Engelhardt, 2012, Gørtz, 2012, Midtsundstad, 2006). However, as previously mentioned, it must be emphasized that the data consisted exclusively of older workers above the age of 60 years. These workers can be assumed to be more healthy and motivated for work than the population of older workers as a whole, since a large proportion of employees retire on the disability pension before they turn 60 (Midtsundstad et al., 2012a). The results from this analysis cannot be generalized outside the age group investigated in this article. Thus, the analysis cannot rule out the possibility that the effect of additional leave as a measure for retaining older workers presupposes a target group which constitutes a relatively healthy and well-motivated group of older workers.

One possible objection to the analysis is that the data used do not enable the possibility of controlling for factors related to health status, the working environment, and working conditions. Nevertheless, controlling for sick absence, level of education, type of occupation, and industry does presumably capture important differences in health, working environment, and working conditions between the intervention and the control group. Furthermore, though the companies are self-selected as to whether additional leave is used as a retention measure, older workers are most likely randomly distributed between the intervention group and the control group. Thus, the health status of the workers in the intervention and control companies is most likely to be randomly distributed and hence not affecting the results of the analysis.

It seems reasonable to assume that the IWLA's goal of increasing the average retirement age has heightened the focus on the labor market situation of older workers and increased employers' awareness of the need to support the continued labor participation of this group. Offering additional leave implies that the employers actively retain older workers and encourage them to continue their working life. Even though additional leave may reduce the effect of "push factors" by helping to reconcile work and leisure, the signal effect embedded in providing this retention measure can be just as decisive in motivating older workers to continue working a few years more. Nevertheless, the ambition of this study was not to investigate whether additional leave helps to counteract more "pull" than "push factors" or vice versa. The aim was to investigate whether additional leave is effective as a retention measure on the whole, controlling for both "pull and push factors" which previous research has shown to affect early retirement behavior. The role played by additional leave as a retention measure and which factors are decisive in the decision to prolong working life will vary between individuals according to different characteristics. Nevertheless, the analysis in this article provides evidence that additional leave is an effective measure for retaining older workers considering early retirement.

The results show that especially having a sick absence, working hours, and type of industry are of significant importance for the individual relative risk of withdrawing a contractual pension. One can question whether the use of standardized retaining measures or a one-size-fits-all approach, such as offering additional leave, is the most appropriate way to retain older workers given the heterogeneity of needs, problems, and challenges facing different industries and groups of employees (Hilsen and Midtsundstad, 2014, Midtsundstad and Bogen, 2011). Furthermore, these measures are also made eligible according to age limits (62 years), which in many sectors and industries are too high to make a difference for individuals at the risk of becoming disabled. Thus, this 
study provides no definitive answer to "what works in age management." If additional leave reduces the effect of "push factors" by helping to reconcile work and leisure, the cost of such a measure must be weighed against the benefits associated with an extended working life. If on the other hand the effect is driven by a signal effect helping to counteract an "early exit" regime, other less expensive measures may have the same effect on the individual risk of retiring early. Furthermore, the present analysis only provides insight into the effect of one single measure use to retain older workers, in a defined period of time for a selected group of employees. Retaining efforts may prove to be more efficient if targeted according to heterogeneity in needs, problems, and challenges facing different industries and groups of employees. Developing more targeted retaining measurers implies a broad collaboration between policymakers, employers' and employees' organizations, and researchers in the field (Hilsen and Midtsundstad, 2014).

\section{Conclusion}

This article has investigated whether additional leave as a measure for retaining older workers had an effect on the relative risk of withdrawing a contractual pension in the next two years of employment among 61- and 62-year-olds during the period from 2001/2002 to $2009 / 2010$. The analysis investigates whether the individual relative risk of retiring early is significantly different for older workers employed in companies that have introduced additional leave compared to those in companies without this retention measure.

Through applying a difference-in-differences approach and controlling for a range of individual and company characteristics, the analysis in this article has estimated the impact of additional leave on early retirement behavior. The analysis does provide evidence for additional leave affecting retirement timing among older workers in Norway. However, the analysis does not indicate which factors of additional leave are decisive in prolonging the working life of older workers in Norway. This article has shown additional leave to be an effective retention measure on early retirement, explaining how the measure impacts the individual's decision to continue working is a challenge for upcoming research requiring additional qualitative methods not used within the scope of this study. Although this study adds to our knowledge in a so far underresearched area, more research is needed before conclusions can be drawn on how to utilize the potential represented by older workers.

\section{Acknowledgments}

I would like to express my deep gratitude to Professor Espen Dahl and Senior Researcher Tove Midtsundstad, my research supervisors, for their guidance, enthusiastic encouragement, and very useful critiques of this research work.

\section{Financial support}

This article has been financed by The Research Council of Norway as part of the project "Senior Policy for Whom? The Distributional Consequences and Effects of Initiatives to Promote Active Ageing 218364" 


\section{References}

Angrist, J. D., \& Pischke, J. S. (2008) Mostly harmless econometrics: An empiricist's companion. Princeton: Princeton University Press.

Buchholz, S., Hofäcker, D., \& Blossfeld, H. P. (2006) 'Globalization, accelerating economic change and late careers. A theoretical framework'. In Blossfeld, H.-P., Buchholz, S., \& Hofäcker, D. (eds.): Globalization, uncertainty and late careers in society. London, New York: Routledge, 1-23.

Börsch-Supan, A., Brugiavini, A., \& Croda, E. (2009) 'The role of institutions and health in European patterns of work and retirement'. Journal of European Social Policy, 19, 341-358.

Calvo, E., Sarkisian, N., \& Tamborini, C. R. (2013) 'Causal effects of retirement timing on subjective physical and emotional health'. The Journals of Gerontology Series B: Psychological Sciences and Social Sciences, 68, 73-84.

Charles, K. K., \& DeCicca, P. (2007) 'Hours flexibility and retirement'. Economic Inquiry, $45,251-267$.

Conen, W. S., Henkens, K., \& Schippers, J. (2011) 'Are employers changing their behavior toward older workers? An analysis of employers' surveys 2000-2009'. Journal of Aging \& Social Policy, 23, 141-158.

Conen, W. S., Henkens, K., \& Schippers, J. (2012) 'Employers' attitudes and actions towards the extension of working lives in Europe'. International Journal of Manpower, 33, 648-665.

Disney, R. (1996) Can we afford to grow older? London: MIT Press.

Dorn, D., \& Sousa-Poza, A. (2010) 'Voluntary'and 'involuntary'early retirement: an international analysis'. Applied Economics, 42, 427-438.

Engelhardt, H. (2012) 'Late careers in Europe: Effects of individual and institutional factors'. European Sociological Review, 28, 550-563.

Esping-Andersen, G. (2000) 'The sustainability of welfare states into the twenty-first century'. International Journal of Health Services, 30, 1-12.

Flynn, M. (2010) 'Who would delay retirement? Typologies of older workers'. Personnel Review, 39, 308-324.

Gambetta, D. (1987) Were they pushed or did they jump? Individual decision mechanisms in education. Cambridge: Cambridge University Press.

Gielen, A. C. (2009) 'Working hours flexibility and older workers' labor supply'. Oxford Economic Papers, 61, 240-274.

Gruber, J., \& Wise, D. A. (2007) Social security programs and retirement around the world: Fiscal implications of reform. Chicago: University of Chicago Press.

Gruber, J., \& Wise, D. A. (2010) Social security programs and retirement around the world: The relationship to youth employment. Chicago: University of Chicago Press.

Gørtz, M. (2012) 'Early retirement in the day-care sector: The role of working conditions and health'. European Journal of Ageing, 9, 1-12.

Haga, O. (2010) Expected retirement age 1986-2009. [Forventa pensioneringsalder 19862009]. Arbeid og velferd nr. 2/2010, Oslo: Arbeids og velferdsdirektoratet.

Hallberg, D. (2007) Older workers work opportunities and employment possibilities. A literature review [Äldres arbetsutbud och möjligheter till sysselsättning, en kunskapsöversikt], DS 2007: 21, Ministry of Finance, Sweden.

Halvorsen, K. (1977) Work or social insurance? [Arbeid eller trygd?]. Oslo: Pax.

Hank, K. (2004) 'Effects of early life family events on women's late life labour market behaviour. An analysis of the relationship between childbearing and retirement in Western Germany'. European Sociological Review, 20, 189-198.

Hauge, L., \& Årethun, T. (2008) Who retires on AFP? [Kven går av med AFP?], Oslo, NAV. NAV-rapport nr. 3. Oslo: Seksjon for statistikk og utredning, Arbeids- og velferdsdirektoratet. 
Hedström, P. (2005) Dissecting the social: On the principles of analytical sociology. Cambridge: Cambridge University Press.

Hernæs, E., Røed, K., \& Strøm, S. (2002) Employment, retirement and economic incentives. [Yrkesdeltakelse, pensjoneringsadferd og økonomiske insentiver.] Oslo: Stiftelsen Frischsenteret for samfunnsøkonomisk forskning.

Hilsen, A. I., \& Midtsundstad, T. (2014) Seniorpolicy-The need for a new map and compass? [Seniorpolitikk—behov for nytt kart og kompass?] Søkelys på arbeidslivet, 1-2, 157-182.

Hofäcker, D. (2010) Older workers in a globalizing world: An international comparison of retirement and late-career patterns in Western industrialized countries. Cheltenham, England: Edward Elgar Publishing.

Hutchens, R. (2010) 'Worker characteristics, job characteristics, and opportunities for phased retirement'. Labour Economics, 17, 1010-1021.

Jensen, P. H., \& Øverbye, E. (2013) ‘The work-retirement puzzle’. In Jensen, P. H., \& Øverbye, E. (eds.): Down and out-Or free at last? Berlin: Logos Verlag, 9-27.

Kooij, D. T., Guest, D. E., Clinton, M., Knight, T., Jansen, P. G., \& Dikkers, J. S. (2013) 'How the impact of HR practices on employee well-being and performance changes with age'. Human Resource Management Journal, 23, 18-35.

Lancee, B., \& Radl, J. (2012) 'Social connectedness and the transition from work to retirement'. The Journals of Gerontology Series B: Psychological Sciences and Social Sciences, 67, 481-490.

Latulippe, D., \& Turner, J. (2000) 'Partial retirement and pension policy in industrialized countries'. International Labour Review, 139, 179-195.

Leiulfsrud, H., Bison, I., \& Jensberg, H. (2005) Social class in Europe. European Social Survey 2002/3. Trondheim: NTNU Samfunnsforskning.

Lien, O. C. (2013) Few change jobs after the age of 50. [Få bytter jobb etter fylte 50 år.] Arbeid og velferd nr. 1/2014, Oslo: Arbeids og velferdsdirektoratet.

Meier, V., \& Werding, M. (2010) 'Ageing and the welfare state: Securing sustainability'. Oxford Review of Economic Policy, 26, 655-673.

Midtsundstad, T. (2002) AFP-retiree: Tired-Or healthy and able-bodied? [AFP-pensjonisten: sliten-eller frisk og arbeidsfør?: en analyse av tidlig pensjonering og bruk av AFP $i$ privatsektor]. Oslo: Forskningsstiftelsen FAFO.

Midtsundstad, T. (2004) How many are entitled to contractual pension? [Hvor mange har rett til AFP?] Oslo: Forskningsstiftelsen FAFO.

Midtsundstad, T. (2005) 'Not necessarily tired ... An analysis of public sector AFP retirement'. ['Ikke nødvendigvis sliten... En analyse av AFP-pensjonering i staten']. Søkelys på arbeidslivet, 2, 217-232.

Midtsundstad, T. (2006) How to prolong a career-A review of Norwegian and international research on early retirement and senior policy. [Hvordan bidra til lengre yrkeskarrierer?: erfaringer fra norsk og internasjonal forskning om tidligpensjonering og seniortiltak]. Oslo: Forskningsstiftelsen FAFO.

Midtsundstad, T. (2007) From exclusion to inclusion? A survey of Norwegian companies' labour strategies for older workers. [Fra utstøting til inkludering?: en kartlegging av norske virksomheters arbeidskraftstrategier overfor eldre arbeidstakere]. Oslo: Forskningsstiftelsen FAFO.

Midtsundstad, T. (2008) 'The company as social policy actor'. ['Virksomheten som sosialpolitisk aktør'.] Tidsskrift for Velferdsforskning, 1.

Midtsundstad, T. (2009) Better health, less toil and more family. [Bedre helse, mindre slit og mer familie]. Oslo: Forskningsstiftelsen FAFO.

Midtsundstad, T. (2011) 'Inclusive workplaces and older employees: An analysis of companies' investment in retaining senior workers'. The International Journal of Human Resource Management, 22, 1277-1293. 
Midtsundstad, T., \& Bogen, H. (2011) Different work-Different needs. Senior policy in Norway. [Ulikt arbeid-ulike behov: seniorpolitisk praksis i norsk arbeidsliv]. Oslo: Forskningsstiftelsen FAFO.

Midtsundstad, T., \& Nielsen, R. A. (2013) Work, pension or both? [Arbeid, pensjon eller begge deler?] Oslo: Forskningsstiftelsen FAFO.

Midtsundstad, T., Hermansen, A., \& Nielsen, R. A. (2012a) 'Effects of companies' initiatives to reduce early retirement among older workers'. Nordic Journal of Working Life Studies, 2, 89-108.

Midtsundstad, T., Nielsen, R. A., \& Hermansen, Å. (2012b) 'Work adaptations and senior measures-Do they influence municipal sickness leave and early retirement?' ['Tilrettelegging og seniortitak-påvirker det kommuneansattes sykefravær og tidligpensjonering?'] Søkelys på arbeidslivet, 29, 130-150.

Nergaard, K. (2009) Who do not have a contractual pension? An analysis based on administrative data. [Hvem har ikke AFP? En analyse med basis i registerbaserte data], Oslo: Forskningsstiftelsen FAFO.

OECD (2013) Ageing and employment policies: Norway 2013 working better with age. Paris: OECD.

Oude Hengel, K. M., Blatter, B. M., Geuskens, G. A., Koppes, L. L., \& Bongers, P. M. (2012) 'Factors associated with the ability and willingness to continue working until the age of 65 in construction workers'. International Archives of Occupational and Environmental Health, 85, 783-790.

Reichborn-Kjennerud, K., Gamperiene, M., \& Hilsen, A. I. (2011) “"Make me an offer I can't refuse"-Do extra days off contribute to seniors staying at work longer?' Older Workers in a Sustainable Society. Frankfurt: Peter Lang Publishing Group.

Taylor, P. (2006) Employment initiatives for an ageing workforce in the EU15. Luxembourg: The European Foundation for the Improvement of Living and Working Conditions.

Van Dalen, H. P., Henkens, K., \& Schippers, J. (2009) 'Dealing with older workers in Europe: A comparative survey of employers' attitudes and actions'. Journal of European Social Policy, 19, 47-60.

Van Dalen, H. P., Henkens, K., \& Schippers, J. (2010) 'How do employers cope with an ageing workforce? Views from employers and employees'. Demographic Research, 22, 1015-1036.

Wooldridge, J. M. (2005) 'Fixed-effects and related estimators for correlated random-coefficient and treatment-effect panel data models'. Review of Economics and Statistics, 87, 385-390.

Wooldridge, J. M. (2009) Introductory econometrics: A modern approach. Mason, OH: Thomson/South-Western.

\section{End notes}

${ }^{1}$ In the government sector the social partners have agreed upon eight additional days of leave from the age of 62 years, formalized in the collective agreement. Six days more additional leave can be agreed upon on a voluntary basis.

2 The contractual early retirement scheme was initially introduced in 1988 . The scheme granted the employees of companies bound by a collective agreement the opportunity to retire from the age of 62 years. Almost $80 \%$ of older workers $(40 \%$ in the private sector) are entitled to benefits from the contractual early retirement scheme (AFP), which is financed by employers and the state in collaboration. 
3 The Register of Business Companies is responsible for registering all Norwegian and foreign business companies in Norway.

4 Estimated by the margins command and substantiated by a linear probability model.

5 The analysis is based on information about whether the companies have introduced additional leave as a retention measure, and not information about whether older workers actually opt for more additional annual leave. Thus, the effect must be interpreted as an intention to treat effect. 